\title{
Factors Influencing the Implementation of Non-profit Organization Financial Statements of Political Parties: Evidence from Indonesia
}

\author{
Bambang JATMIKO ${ }^{1}$, Titi LARAS ${ }^{2}$, Anatya WIJAYANTI ${ }^{3}$
}

Received: July 03, 2020 Revised: September 20, 2020 Accepted: October 05, 2020

\begin{abstract}
This study aims to find out whether political parties apply financial reports under PSAK (Statement of Financial Accounting Standards) No. 45. The Stewardship Theory provides the analytical framework. The objects in this study were 16 Yogyakarta City Political Parties in the Special Region of Yogyakarta, with the total number of 64 respondents. The application for processing data in this study used SPSS 22 version. Based on the results of analyzing data, H1, which had a sig (2-tailed) value of $0.026<0.05$, then $\mathrm{H} 0$, stating that there was an influence of the statement of financial position on the implementation of PSAK, was rejected. H2 had a sig (2-tailed) value of $0.116>0.05$, so that $\mathrm{H} 0$, stating that there was no significant effect of the activity report on the implementation of PSAK, was accepted. H3 had a sig (2-tailed) value of $0.027<0.05$, meaning that it rejected $\mathrm{H} 0$, which stated that there was a significant effect of the cash flow statement on the implementation of PSAK. Furthermore, H4 had a sig (2-tailed) value of $0.744>0.05$, indicating that H0 was accepted, stating that there was a significant effect of notes to the financial statements on the implementation of PSAK.
\end{abstract}

Keywords: Financial Statements, Non-profit Organizations, Political Parties, Indonesia

JEL Classification Code: L30, L31, L32

\section{Introduction}

Based on their purposes, organizations are categorized as profit-making organizations and non-profit-making organizations or non-profit organizations. Non-profit organizations in Indonesia are growing more and more (Aldiansyah, 2017). According to Sujarweni (2015), nonprofit organizations obtain resources from the contributions of members and other contributors who do not expect any compensation from the organization. The characteristic of a non-profit organization lies in ownership. Ownership in a

${ }^{1}$ First Author and Corresponding Author. Lecturer, Business and Economic Faculty, Universitas Muhammadiyah Yogyakarta, Indonesia [Postal Address: Jl. Brawijaya, Tamantirto, Kec. Kasihan, Yogyakarta, 55183, Indonesia]

Email: bambang_jatmiko65@yahoo.com

${ }^{2}$ Lecturer, Economic Faculty, Universitas Janabadra Yogyakarta, Indonesia

${ }^{3}$ Lecturer, Business and Economic Faculty, Universitas Muhammadiyah Yogyakarta, Indonesia

(c) Copyright: The Author(s)

This is an Open Access article distributed under the terms of the Creative Commons Attribution Non-Commercial License (https://creativecommons.org/licenses/by-nc/4.0/) which permits unrestricted non-commercial use, distribution, and reproduction in any medium, provided the original work is properly cited. non-profit entity cannot be sold, transferred, or redeemed as in the case of a business entity. Besides, in the way nonprofit organizations obtain resources from donors and other members, ideally, they do not expect a refund for their operating activities (Hendrawan, 2011). The Indonesian Association of Accountants has the authority to set specific standards for non-profit organizations in Statement of Financial Accounting Standards (PSAK) No. 45 (Revised 2011) concerning financial reporting of non-profit entities, so that a non-profit entity in preparing its financial statements in reference to PSAK No. 45. Non-profit entities are expected to make reporting that has high comparability and relevance with the reporting guidelines. According to Law Number 2 of 2011, political parties are organizations formed because of the common ground of the will and ideals to fight for political interests (Muchamad, 2011).

According to Rahman (2007), a political party is a group of citizens who aim to implement government policy. A political party is a group of people who have the same ideology (Inu, 2005). PSAK No. 45 is the basis of guidelines in preparing the financial statements of non-profit political party organizations. The main difference between non-profit organizations and business organizations lies in the way non-profits get funds from the contributions of members and 
other donors who do not expect any reward (Hafild, 2008). Financial assistance from political parties is used as funds to support political education activities and the operations of the political party secretariat. Financial reports must be provided by political parties include: a) reports on the realization of the political party's budget; b) balance sheet report; and c) cash flow statement (IAI, 2009).

The use of Political Assistance Funds above has been regulated by Permendagri (Regulation of the Minister of Home Affairs) Number 77 of 2014 Chapter VII Article 24, which reads: (1) the financial assistance of political parties is used as funds to support political education activities and the operations of the political party secretariat; (2) the use of political education, as referred to in paragraph (1) is at least $60 \%$ of the amount of assistance received; (3) political education activities as referred to in paragraph (2) are carried out following the laws and regulations governing political education. Research conducted by Aldiansyah and Lambey (2017) showed that the government primary schools had made financial reports as simple as a cash receipt book, a cash disbursement book, a recapitulation book, and did not make the statement as stipulated in PSAK No. 45.

Furthermore, research conducted by Kumambow et al. (2015) shows that arranging the financial statements was based on church ordinances. The financial reports were made in the form of a budget realization report, containing the income and expenditure of the church during the current year. Also, the financial statements would be more relevant, reliable, and could be compared so that the accountability of the financial statements was more adequate. In addition, research conducted by Wonok (2016) reveals that the GMIM Congregation Imanuel Leilem had not implemented PSAK No. 45, regarding the Financial Reporting of Nonprofit Entities in its financial statements, and used financial statements that were mutually agreed upon by the church organization.

\section{Literature Review}

\subsection{Stewardship Theory}

The Stewardship Theory derives from a perspective of management accounting thinking mainly based on psychological theories and sociology. In managing the Stewardship Theory, organizational management is focused on the harmonization between the capital owners (principles) and the capital managers (stewards) in achieving common goals (Alam et al., 2020; Hardiningsih et al., 2020; Rahman \& Saima, 2018). Stewardship Theory in accounting explains the construct of leadership patterns and communication relationships between shareholders and management, or can it can also be a relationship between top management and managers who are below it in a company organization, with situational mechanisms that include management philosophy and differences in organizational culture, and leadership in achieving common goals without obstructing each other's interests (Anton, 2010)."

In governance, it can be said that the government is a public servant. In another sense, the parties are also part of the government, which is are public servants to convey the aspirations of the community to the government. The government and the parties will not run well without the community. The people here can be said to be kings because, in essence, the government does regulate the people according to legal regulations. Still, the community also has the right to receive services from the government. The connection with the financial statements of political parties is that the community can prosper in terms of infrastructure and education that can be sourced from public finances. Non-profit organizations or political parties are also sourced from the community itself because people pay part of the results of their work to the government. Political parties get APBD/APBN (State Revenue and Expenditure Budget/ Regional Revenue and Expenditure Budget) sourced from the government. In other words, it is the community that pays the government and political parties in Indonesia. Also, the public has the right to know the transparency of the financial statements of political parties, which are the means of conveying people's aspirations.

\subsection{Non-profit Organization}

A non-profit organization is an organization that has, as its main objective, to support an issue or matter in attracting public attention to a non-commercial purpose, without any consideration of the problems that are for-profit (monetary). Non-profit organizations include churches, public schools, public charities, hospitals and public clinics, political organizations, community assistance in legislation, voluntary service organizations, trade unions, professional associations, research institutes, museums, and several government officials (Kumambow, 2015). Non-profit organizations have the following characteristics:

a. Entity resources: entity resources come from contributors who do not expect repayments or economic benefits that are proportional to the number of resources provided.

b. Producing goods/services without the aim of accumulating profits: if an entity makes a profit, then the amount is never shared with the owners of the entity.

c. There is no ownership, as is usual in business organizations: it is in the sense that ownership in a non-profit organization cannot be sold, transferred, or redeemed, or the ownership does not reflect the proportion of the entity's resource distribution in an entity's liquidation (Hasana, 2011). 


\subsection{Financial Statements}

Basically, financial statements are the result of an accounting process that can be used as a tool to communicate between company activities and those who have an interest in these activities (Nanu, 2011). Kieso (2011) revealed that financial statements are the primary means for a company to communicate financial information to outside parties. This report provides information about company history measured in terms of money (Khajar et al., 2019).

\subsection{Political Party}

Political parties are groupings of citizens based on common thoughts and political interests. The political participation of the people has increased the development of democracy in the life of the state. Political parties are the most critical institutional means to organize the expansion of political participation (Huntington, 2003). According to Budiardjo (2008), political parties consist of organized members with the same ideals. Edmund Burke defines political parties as a single organizational structure that aims to disseminate efforts that have become an agreement among them for the national interest.

In the same way, Ware (1996) concluded that a political party is an institution that influences the state by controlling strategic positions in government. Usually, political parties have more than one interest and try to fight for these interests. For Budiardjo, a political party is an organized group in which its members have the same orientation, values, and ideals. The purpose of this group is to gain power, politics, and seize political position constitutionally to carry out their interests (wisdom) (Ridho, 2013). Correspondingly, the understanding of political parties, according to Law Number 2 of 2008, is a national organization formed by a group of Indonesian citizens voluntarily based on the common will and aspirations to fight for and defend the political interests of members, society, nation, and state, as well as to maintain the integrity of the Unitary Republic of Indonesia based on Pancasila and the 1945 Constitution of the Republic of Indonesia. The formation of political parties consists of at least 50 citizens who are at least 21 years old with a notarial deed. Its establishment and formation include a 30\% representation of women (Muchamad, 2011).

\section{Hypothesis Development}

\subsection{Financial Position Report on Political Parties}

The statement of financial position covers the nonprofit organization as a whole, presenting total assets, liabilities, and net assets. Then, according to Law Number 2 of 2011, Political Parties are organizations formed because of the common ground of the will and ideals to fight for political interests (Muchamad, 2011). One form of nonprofit organizations is a political party. According to research conducted by Repi (2015), the results showed that non-profit organizations studied had not yet applied the financial position statement. In another study, Pontoh (2013) showed that the non-profit organizations researched, Bukit Zaitun Church, has not yet prepared a statement of financial position implemented by the Indonesian Association of Accountants. Furthermore, research conducted by Tinungki and Pusung (2014) showed that the non-profit organization, Social Institution Tresna Werdha Hana, has not filed the statement of financial position in accordance with Statement of Financial Accounting Standards No. 45.

H1: The statement of financial position PSAK No. 45 has not been applied to the financial statements of nonprofit organizations

\subsection{Activity Report on Political Parties}

The activity report covers the non-profit as a whole and presents changes in the number of net assets during a period. In this case, according to Law Number 2 of 2011, political parties are organizations formed because of the common ground of the will and ideals to fight for political interests (Muchamad, 2011). One form of non-profit organizations is political party. Nurlaela and Mutmainah (2014) revealed that non-profit public-service agencies have presented activity reports in accordance with PSAK No. 45, which could be seen in the components of the financial statements, including the statement of financial position, statement of activities, statement of cash flows, and notes to the financial statements.

Furthermore, research conducted by Kumambow et al. (2015) showed that the applied non-profit organization, GMIM Bukit Zaitun Walian Dua Church, prepared its financial statements based on the church's order, where the financial reports were made in the form of a budget realization report containing the income and expenditure of the church during the year. Meanwhile, research by Pontoh (2013) indicated that the non-profit organization had implemented an activity report in accordance with Statement of Financial Accounting Standards No. 45, even though the organization did not present cash flow statements, statement of financial position, and notes to the financial statements.

H2: The activity report of PSAK No. 45 has been applied in the non-profit organizations

\subsection{Cash Flow Statement on Political Parties}

Statements of cash flows must report cash flows for a certain period and are classified according to operating, 
investing, and financing activities. Whereas, according to Law Number 2 of 2011, political parties are organizations formed because of the common ground of the will and ideals to fight for political interests (Muchamad, 2011). Marlinah and Ibrahim (2018) revealed negative results, non-profit organizations have not yet implemented the cash flow statement that has been set by the Indonesian Institute of Accountants namely PSAK No. 45. Moreover, research conducted by Andarsari (2012) showed that non-profit organizations, mosque institutions, have not yet implemented a cash flow statement. The non-profit organization faced obstacles in its financial statements. Although the form was a non-profit organization, PSAK No. 45 states that non-profit organizations have the right and must make financial reports as a form of accountability to donors and the surrounding community, who were worshipers in the mosque. Whereas, Nikmatuniayah and Marliyati (2015) indicated that nonprofit organizations in the form of amil zakat institutions in the city of Semarang have not provided financial reports in accordance with PSAK No. 45, which means that the cash flow statement has not been applied in the financial statements.

H3: The cash flow statement of PSAK No. 45 has not been applied to the financial statements of non-profit organizations

\subsection{Notes on Financial Reports to Political Parties}

Notes to the financial statements can be in the form of: (a) details of an estimate presenting, for example, fixed assets; and (b) the accountant's policy adopting, for example, the method of depreciation and the rates used for the fixed assets of the institution, the method of recording accounts receivable that can not be billed, and the percentage used for the allowance (Janis, 2017). Moreover, according to Law Number 2 of 2011, political parties are organizations formed because of the common ground of the will and ideals to fight for political interests (Muchamad, 2011). Research conducted by Gultom and Poputra (2015) showed that nonprofit organizations in the form of GMIM synod offices have not implemented financial reports under PSAK No. 45. The GMIM synod office has so far only compiled reports on the realization of the expenditure and income budget following the directions contained in the order of the Evangelical Church in Minahasa. The GMIM synod office has not yet complied with the administration because it has not presented it in the same way as its notes to the financial statements.

Further, Wonok (2016) revealed that the GMIM congregation Imanuel Leilem has not implemented PSAK No. 45 and used financial statements that were jointly agreed to by their church organization. Whereas, Janis and Budiarso (2017) indicated that non-profit organizations in GMIST PNIEL Biau Kab, Kep. Sitaro has not adopted PSAK No. 45 regarding the presentation of its financial statements, but the church continued to prepare financial statements of realization of income and expenses under GMIST No. 6 .

\section{Methodology}

The data used in this study were primary data obtained directly from the respondents through questionnaires distributed to 16 political parties in Yogyakarta City. Further, binary logistic regression analysis is used to explain the relationship between response variables in the form of dichotomic/binary data with independent variables in the form of interval or categorical data. Binary logistic regression does not assume the relationship between independent and dependent variables in a linear fashion. Binary logistic regression is a non-linear regression where the specified model will follow the curve pattern, as shown in Figure 1.

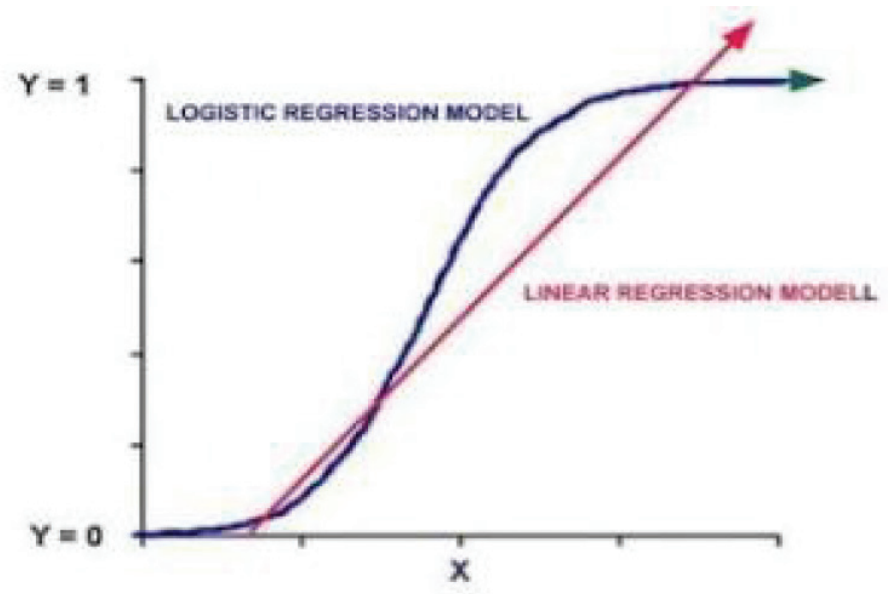

Figure 1: Binary Logistic Regression Analysis Curves 
Binary logistic regression is actually the same as multiple regression analysis, and only the dependent variable is a dummy variable (0 and 1$)$. It was as research analysis of the application of non-profit financial statements based on PSAK No. 45 on the political party of the city of Yogyakarta. The independent variables were the statement of financial position, activity report, statement of cash flows, and notes to the financial statements. In contrast, the dependent variable was the political party in the city of Yogyakarta. This research examined whether or not to apply the independent variable to the dependent variable. Then, the dependent variable was 1 if it applied and 0 if it did not apply.

\section{Results}

Descriptive statistical analysis test aimed to present the amount of data, the maximum and minimum values, the mean and the standard deviation (standard deviation) for the variables in this study. Of all the variables put together, the minimum value was -2.362 , the maximum value was 1.437 , the mean was 0.041 , the standard deviation was 1.139 , and the range was 3.799 for all variables.

\subsection{Block 0: Beginning Block}

Based on the results, the -2 Log Likelihood value was 87,154 , which would be compared to chi-square at a significance level of 0.05 , with df as big as N-1. N was the number of samples, meaning $64-1=63$. From the chi-square, the value was 82.529 . Thus, $-2 \log$ Likelihood $>$ chi-square $(87,154>82,529)$. If the constants were categorized as decent, all independent variables entered were also decent. However, there was a decrease of -2 Log Likelihood, which was 87,157-75,901 = 11.25.

The output was a block or initial block, which was the initialization process. It means that the variables $\mathrm{X} 1, \mathrm{X} 2, \mathrm{X} 3$, and $\mathrm{X} 4$ had not been included in the research model. In other words, this model was a logistic equation model that only used constants to predict respondents into the category of not setting or setting financial statements of PSAK No. 45. From the significance value, it was known that the resulted constant was $0.213(>0.05)$. It means that using a simple equation model (only constants) had not been able to explain the proportions stipulating the financial statements of PSAK No. 45. Furthermore, it can be seen in Block 1 output.

\subsection{Block 1: Method $=$ Enter}

The results obtained a Sig. Model value of 0.020 . Because this value was less than $5 \%$, H0 was rejected at the $5 \%$ significance level. Thus, it was concluded that the independent variables used together influenced the accuracy of the financial statements of an agency. Otherwise, at least one free variable was affected.
The percentage of model accuracy in classifying observations was $70.3 \%$. It means that from 64 observations, 45 observations were classified correctly by the logistic regression model. The correct number of observations for classification can be seen on the main diagonal.

From the results, it can be seen that, by entering four independent variables, the model apparently has changed in the parameter estimation (-2 Log Likelihood) of 75.434. It can be seen that the value of R-Square is as much as 0.167 or $16.7 \%$ (Cox \& Snell), and 0.225 or $22.5 \%$ (Nagelkerke). Thus, it can be interpreted that, with four variables, namely, the statement of financial position, the statement of activities, the statement of cash flows, and the notes to the financial statements, the proportion applying the PSAK financial statements No. 45 can be explained by $22.5 \%$. However, keep in mind that this interpretation was only the value of the approach, as in the coefficient of determination (ordinary linear regression).

The hypothesis is:

- $\mathrm{H} 0=$ The model is sufficient to explain the data (Goodness of fit)

- $\mathrm{H} 1=$ The model is not sufficient to explain the data

If the $p$-value was not significant $(0.488>0.05)$, then $\mathrm{H} 0$ was accepted. In contrast, if the resulting chi-square test had no significance p-value of $0.10>0.05$, then $\mathrm{H} 0$ was accepted. Thus, the conclusion is that the model had sufficiently explained the data (goodness of fit).

The null hypothesis (H0) is rejected if the p-value is significant $<0.05$. The $\mathrm{p}$-value of the variable $\mathrm{X} 1$ significance of the financial position statement was $0.026<0.05$, then $\mathrm{H} 0$ was rejected. It can be concluded that there was a significant influence of the Financial Position Statement on the application of PSAK financial statements No. 45 for political parties, with an influence coefficient of 1.384. It means that out of all 16 political parties, they applied variable X1 more, namely, the statement of financial position at a coefficient of 1.384.

The $\mathrm{p}$-value of the variable $\mathrm{X} 2$ significance of the activity report was $0.116>0.05$, so $\mathrm{H} 0$ was accepted. It can be concluded that there was no significant effect of the Activity Report on the application of PSAK financial statements No. 45 for political parties, with an influence coefficient of $-1,210$. It means that out of all 16 political parties, a small number applied the $\mathrm{X} 2$ variable of activity report, which was equal to a coefficient value of $-1,210$.

The p-value of the variable X3 significance of the cash flow statement was $0.027<0.05$, meaning that $\mathrm{H} 0$ was rejected. It can be concluded that there was a significant influence of the Cash Flow Statement on the application of PSAK financial statements No. 45 on political parties, with an influence coefficient of 1.658. It indicates that of the 16 political parties, many of them implemented the X3 variable of activity report, with a coefficient of 1.658 . 
The p-value of the variable X4 significance of the notes on the financial statements was $0.744>0.05$, then $\mathrm{H} 0$ was accepted. It can be concluded that there was a significant effect of Notes to the Financial Statements on the application of PSAK financial statements No. 45 on political parties, with an influence coefficient value of -0.234 . It signifies that out of 16 political parties, a few implemented the $\mathrm{X} 4$ variable of notes to the financial statements, with a coefficient value of -0.234 .

Based on the results, the odds ratio can be interpreted as follows:

- If the Financial Position Report increased by 1 , the tendency to adopt PSAK financial statements No. 45 in political parties was 3.992 times.

- If the Activity Report increased by 1 , the tendency to apply PSAK financial statements No. 45 in political parties was 0.298 times.

- If the Cash Flow Statement increased by 1 , the tendency to implement PSAK financial statements No. 45 in political parties became 5.247 times.

- If the Notes to the Financial Statements increased by 1 , the tendency to employ the PSAK financial statements No. 45 in political parties was 0.791 times.

\section{Discussion}

\subsection{Financial Position Statement on Political Parties}

As per the results of the first hypothesis (H1), it is known that the variable statement of financial position (X1) had a sig value (2-tailed) of $0.026<0.05$ meaning that $\mathrm{H} 0$ was rejected. The null hypothesis ( $\mathrm{H} 0)$ was rejected if the significance $\mathrm{p}$-value was $<0.05$. It was concluded that there was an influence of the statement of financial position on the application of PSAK financial statements No. 45 on political parties, with an influence coefficient of 1.384. It means that the political party's financial statements have presented assets on the statement of financial position.

The total assets of political parties' financial statements have presented cash and cash equivalents, accounts receivable, inventories, insurance, securities, and information. Those were presented by political parties on the statement of the financial position of the cash and cash equivalents, with clear explanations regarding the use of donations. The financial statements of political parties have presented liabilities in the statement of financial position. Liabilities in political parties' financial statements have provided accounts payable, prepaid income, and long-term debt. Besides, the information presented on the statement of financial position liabilities could be understood by contributors. The financial statements of political parties have presented net assets in the statement of financial position.
Net assets in the statement of financial position of political parties have presented net assets not bound, net assets temporarily bound, net assets permanently bound. Contributors could understand that information presented in the net assets of financial position statements. From all 16 political parties, many implemented the variables of a financial position statement (X1), which was equal to a coefficient value of 1.384 , showing a positive number. The observation revealed that political parties implemented financial statements in accordance with PSAK No. 45 were 23 respondents from 64 respondents. Meanwhile, political parties applying financial statements but not according to PSAK No. 45 were 14 respondents out of 64 respondents. From 16 political parties, the total number of political parties that implemented it was 10 , with a percentage of $62.2 \%$.

The results of this study are in line with research conducted by Repi (2015), which showed that the nonprofit organization has not yet implemented the financial position statement. In other studies, Pontoh (2013) revealed that non-profit organization, Bukit Zaitun Church, has not yet prepared the financial position statement implemented by the Indonesian Association of Accountants. Furthermore, Tinungki and Pusung (2014) found that the non-profit organization, Social Institution Tresna Werdha Hana, has not applied the statement of financial position in accordance with Statement of Financial Accounting Standards No. 45. The statements of financial position include non-profit organizations as a whole, presenting total assets, liabilities, and net assets. According to Law Number 2 of 2011, political parties are organizations formed because of the common ground of the will and ideals to fight for political interests (Muchamad, 2011), and one form of non-profit organizations is political party.

\subsection{Activity Report on Political Parties}

As per the results of the second hypothesis (H2), it is known that the activity report variable (X2) had a sig (2-tailed) value of $0.116>0.05$, so that $\mathrm{H} 0$ was accepted. The null hypothesis (H0) was accepted if the significance p-value was $>0.05$. It was concluded that there was no significant effect of the activity report on the adoption of PSAK financial statements No. 45 on political parties, with an influence coefficient of -1,210. It was for which the financial statements of political parties did not present income on activity reports. Information presented by political parties on the income from activity reports did not provide services, did not present donations, and did not present investment income. Furthermore, political party financial statements did not present expense on activity reports. The information presented in the activity report expense did not present expenses related to the service delivery program, did not present expenses associated with supporting activities. 
Moreover, according to political parties, the expense of activity reports did not present additional information regarding expenses based on their nature.

Out of all 16 political parties, only a few applied the activity report variable (X2) at a coefficient value of -1.210 , which indicated a negative number. The observation results revealed that political parties that did not apply financial statements under PSAK No. 45 were five respondents from 64 respondents. In comparison, those who did not implement financial statements included 22 respondents from 64 respondents. The total number of political parties that applied it was six out of 16 political parties or $37.8 \%$.

The results of this study are not in line with the research conducted by Kumambow et al. (2015), which showed that the non-profit organization that implemented it was the GMIM Church Bukit Zaitun Walian Dua. It compiled the financial statements based on the church's order, in which the financial statements were made in the form of a budget realization report that contained the income and expenditure of the church during the year. Whereas, Pontoh (2013) indicated that the non-profit organization had implemented an activity report following Statement of Financial Accounting Standards No. 45, even though the organization did not present cash flow statements, statement of financial position, and notes to the financial statements. The activity report covered the non-profit as a whole and presented changes in the number of net assets during a period. In this case, according to Law Number 2 of 2011, political parties are organizations formed because of the common ground of the will and ideals to fight for political interests (Muchamad, 2011).

\subsection{Cash Flow Statement on Political Parties}

As per the results of the third hypothesis (H3), it was known that the variable cash flow statement (X3) had a sig (2-tailed) value of $0.027<0.05$, meaning that $\mathrm{H} 0$ was rejected. The null hypothesis (H0) was rejected if the significance p-value was $<0.05$. It was concluded that there was a significant effect of the Cash Flow Statement on the adoption of PSAK financial statements No. 45 on political parties, with an influence coefficient of 1.658 .

It indicated that the financial statements of political parties had presented cash flow from operating activities, cash flow from investment activities, cash flow from funding activities, and cash flow from other funding activities. The information presented on the cash flow from operating activities, cash flow from investment activities, cash flow from funding activities, and cash flow from other funding activities was complete in the recording.

The information presented on the cash flow from operating activities had recorded that the net cash received was used for investment activities. Then, the information presented on the cash flow from investment activities had been complete recording receipts from investment sales. In addition, the information presented on the cash flow from funding activities had recorded investments in endowments futures, building investment, and the annual investment agreement. Also, on cash flows from other funding activities, the information presented had recorded annual liability payments, notes payable, and long-term liabilities.

Out of all 16 political parties, many applied the cash flow statement variable (X3) at a coefficient of 1.658, which indicated a positive number. The observation results displayed that political parties that applied financial statements under PSAK No. 45 were 23 respondents from 64 respondents, while those who were applying financial statements but not according to PSAK No. 45 were 14 respondents out of 64 respondents. The total number of political parties that implemented it was 10 out of 16 political parties or equal to $62.2 \%$.

The results of this study do not support Marlinah and Ibrahim (2018), which showed that the research was negative, in which non-profit organizations had not applied the cash flow statement that had been set by the Indonesian Association of Accountants, namely, PSAK No. 45. Besides, Andarsari (2012) revealed that non-profit organizations, namely, mosque institutions, had not yet implemented a cash flow statement. The non-profit organization faced obstacles in its financial statements. Although the form was a nonprofit organization, PSAK No. 45 states that non-profit organizations have the right and must make financial reports as a form of accountability to donors and the surrounding community who are worshipers in the mosque. Meanwhile, Nikmatuniayah and Marliyati (2015) showed that nonprofit organizations in the form of amil zakat institutions in the city of Semarang had not provided financial reports in accordance with PSAK No. 45, which indicated that the cash flow statement had not been applied in the financial statements.

Statements of cash flows must report cash flows for a certain period and are classified according to operating, investing, and financing activities. Also, according to Law Number 2 of 2011, political parties are organizations formed because of the common ground of the will and ideals to fight for political interests (Muchamad, 2011).

\subsection{Notes on Financial Reports to Political Parties}

As per the results of the third hypothesis (H3), it was known that the variable notes on the financial statements (X4) had a sig (2-tailed) value of $0.744>0.05$, then $\mathrm{H} 0$ was accepted. The null hypothesis (H0) was accepted if the significance p-value was $>0.05$. It was concluded that there was a significant effect of Notes to Financial Statements on the application of PSAK financial statements No. 45 
on political parties, with an influence coefficient of -0.234 . It means that the financial statements of political parties did not present fixed assets from the notes to the financial statements.

The information presented on fixed assets did not provide a record that funds were spent to support political party program activities. The political party financial statements did not show the depreciation method in the notes to the financial statements. The information presented in the notes to the financial statements depreciation method section was not very clear in explaining the percentage of depreciation. Besides, the political party financial statements did not present the depreciation method in the notes to the financial statements. The information presented in the notes to the financial statements section of the recording method for receivables was not clear on the recording of accounts receivable

Of all 16 political parties, only a few applied the variable of note to the financial statements (X4), which was equal to the coefficient value of -0.234 , indicating a negative number. The observation results displayed that political parties, which did not apply financial statements under PSAK NO. 45, were five respondents from 64 respondents, while those who did not apply the financial statements were 22 respondents from 64 respondents. The total number of political parties that implemented it was 6 out of 16 political parties, or equal to the percentage of $37.8 \%$.

The results of this study agree with research by Gultom and Poputra (2015), which showed the results that non-profit organizations in the form of GMIM synod offices had not implemented financial reports in accordance with PSAK No. 45. The GMIM synod office had so far only compiled reports on the realization of the expenditure and income budget in accordance with the directions contained in the administration of the Evangelical Church in Minahasa. The GMIM synod office had not yet complied with the administration because it had not presented it in the same way as the notes to the financial statements. Besides, Wonok (2016) showed that the GMIM congregation Imanuel Leilem had not implemented PSAK No. 45 and used financial statements that were jointly agreed to by their church organization. Whereas, Janis and Budiarso (2017) showed that non-profit organizations in GMIST PNIEL Biau Kab, Kep. Sitaro had not adopted PSAK No. 45 regarding the presentation of its financial statements. Still, the church continued to prepare financial statements of realization of income and expenses in accordance with GMIST No. 6. Notes to the financial statements can be in the form of: (a) details of an estimate presenting, for example, fixed assets; and (b) the accountant's policies carrying out, for example, the method of making deposits and the rates used for the fixed assets of the institution, the method of recording accounts receivable that can not be billed, and the percentage used for the provision (Janis, 2017).
Based on the analysis, it shows the value of 36 from 64 respondents for the results of "Not Implementing" and the value of 28 from 64 respondents for the results of " Implementing." Whereas, the existing percentage was 56.3\% for "Not Implementing" and 43.8\% for "Implementing" of $100 \%$. The conclusion obtained was that of the 16 Political Parties of the City of Yogyakarta in the Special Region of Yogyakarta, only $56.3 \%$ were able to apply financial statements based on PSAK NO. 45, by meeting the variable criteria X1: statement of financial position, X2: statement of cash flows, X3: statement of cash flows, and X4: notes to the financial statements.

\section{Conclusions}

The results of this study concluded the following.

First, there were two hypotheses with a value of X2: $0.116>0.05$, then $\mathrm{H} 0$ was accepted, and $\mathrm{X} 4$ : with a value of $0.744>0.05$, so that $\mathrm{H} 0$ was accepted, from the four hypotheses proposed. Those variables were the activity report and notes on financial statements, which were not often applied by political parties, specifically 16 political parties in Yogyakarta City.

Second, there were two hypotheses with a value of X1 of $0.026<0.05$, resulting in $\mathrm{H} 0$ being rejected, and $\mathrm{X} 3$ with a value of $0.027<0.05$, so that $\mathrm{H} 0$ was rejected, from the four proposed hypotheses. These variables were the statement of financial position and notes to the financial statements, where these two variables were often applied by political parties, specifically 16 political parties. Thus, political parties did not fully use the four factors for implementing the financial statements of nonprofit organizations based on PSAK No. 45.

Third, the predicted factors for applying financial statements of non-profit organizations based on PSAK No. 45 could be found through the data test above. The results showed the value of 36 out of 64 respondents for the results "Not Implementing" and the value of 28 out of 64 respondents for the result "Implementing." Meanwhile, the existing percentage was $56.3 \%$ for "Not Implementing" and $43.8 \%$ for "Implementing" of $100 \%$. The conclusion obtained was that, out of the 16 Political Parties of the City of Yogyakarta in the Special Region of Yogyakarta, only 56.3\% were able to apply financial statements based on PSAK NO. 45 , by meeting the variable criteria X1: statement of financial position, X2: statement of cash flows, X3: statement of cash flows, and $\mathrm{X} 4$ : notes to the financial statements.

Based on this research, several suggestions are proposed:

- It is recommended that further research expand the sample, such as adding several districts or provinces in Indonesia, so that the results obtained can test the theory more thoroughly.

- It is recommended that further research add variables that can influence the application factors of financial 
statements of non-profit organizations based on PSAK No. 45 on political parties.

- It is recommended that further research deepens the application of non-profit financial statements based on PSAK No. 45 on political parties.

\section{References}

Alam, M. K., Tabash, M. I., Thakur, O. A., Sahabuddin, M., Hosen, S., \& Hassan, M. F. (2020). A central Shariah regulatory authority for the Islamic banks in Bangladesh: Legalization or formation. Journal of Asian Finance, Economics and Business, 7(1), 91-100. https://doi.org/10.13106/jafeb.2020. vol7.no1.91

Aldiansyah, \& Lambey, L. (2017). Application of PSAK NO. 45 Revision of 2015 at the Madrasah Ibtidaiyah Baitul Makmur Kotamobagu Foundation. Jurnal Accountability, 6(45), 92-102. [Indonesian]

Andarsari, P. R. (2012). Financial statements of non-profit organizations (mosque institutions). Jurnal Ekonomi Universitas Kediri, 1, 143-152. [Indonesian]

Anton, F. X. (2010). Towards Stewardship Management Theory. Scientific Informatics Magazine, 1(2), 61-80. [Indonesian]

Arif Hidayatullah, Agung Budi Sulistiyo, N. H. (2019). Analysis of the Reconstruction of the Compilation of Financial Reports of the Mosque (Case Study at the Banyuwangi Baiturrahman Great Mosque). Journal of Business Economics and Accounting, 6(1), 69-75. [Indonesian]

Bastian, I. (2007). Accounting for NGOs and Political Parties. Jakarta, Indonesia: Erlangga. [Indonesian]

Budiardjo, M. (2008). The basics of political science. Jakarta, Indonesia: Gramedia pustaka utama. [Indonesian]

Cintokowati, C. (2010). Mosque vs. Church Accounting, Nonprofit Organization. Jakarta, Indonesia: Gramedia pustaka utama. [Indonesian]

Fitri, N. (2019). Analysis of Implementation of Statements of Financial Accounting Standards Number 45 Financial Reporting on the Great Indonesia Movement Party (Gerindra). Lampung, Indonesia: Lampung University Press. [Indonesian]

Gultom, I. R., \& T.Poputra, A. (2015). Analysis of the Application of PSAK NO. 45 About Nonprofit Financial Statements in Achieving Transparency and Accountability of the GMIM Synod Office. EMBA Journal, 3(45), 527-537. [Indonesian]

Halim, A. (2012). Public Sector Accounting for Regional Financial Accounting. Jakarta: Penerbit Salemba Empat. [Indonesian]

Harahap, S. S. (2012). Accounting Theory. Jakarta, Indonesia: PT RajaGrafindo Persada. [Indonesian]

Hardiningsih, P., Udin, U., Masdjojo, G. N., \& Srimindarti, C. (2020). Does Competency, Commitment, and Internal Control Influence Accountability? Journal of Asian Finance, Economics, and Business, 7(4), 223-233. https://doi. org/10.13106/jafeb.2020.vol7.no4.223
Hasana, K. (2011). Characteristics of Nonprofit Organizations. Jakarta, Indonesia: Penerbit Salemba Empat. [Indonesian]

Hendrawan, R. (2011). Analysis of the Application of PSAK No. 45 About the Financial Reporting of Non-Profit Organizations in Hospitals with Public Service Agency Status (Case study in RSUD Kota Semarang). Semarang, Indonesia: Universitas Diponegoro Press. [Indonesian]

Huntington S. P. (2003). Political Order in the Middle of a Shift in Mass Interests. Jakarta: Raja grafindo persada. [Indonesian]

Indratno, A. (2013). Basic Principles of Accounting. Jakarta, Indonesia: Dunia Cerdas. [Indonesian]

Inu. K. S \& Ashari. (2005). Indonesian Political System. Jakarta: PT. Refika aditama. [Indonesian]

Janis, R. S., \& Budiarso, N. S. (2017). Analysis of the Application of PSAK No. 45 About Financial Reporting of Non-profit Entities in GMIST Congregation Pniel Biau Kab, Kep. Sitaro. Accountability, 6(1), 103-111. [Indonesian]

Khajar, I., Hersugondo, H., \& Udin, U. (2019). Privatization and financial performance: Evidence from Indonesia. Quality Access to Success, 20(173), 107-110.

Korompis, C. W. M. (2014). Application of PSAK No. 45 About the Financial Reporting of Nonprofit Organizations at the Logos Ma'AKantar Cultural Arts Studio. Journal of Accounting Research, 9(45), 52-60. [Indonesian]

Kieso, W., \& Kimmel, P. D. (2011). Financial Accounting. Hoboken, NJ: Wiley.

Kumambow, L., Tinangon, J. J., \& Tirayoh, V. Z. (2015). Application of PSAK No. 45 At GMIM Buki Zaitun Walian Dua Church. Journal of Going Concern Accounting Research, 10(2), 66-76. [Indonesian]

Kurniasari, W. (2011). Transparency of Mosque Management with Financial Statements Based on Statements of Financial Accounting Standards (PSAK 45). Journal of Muqtasid, 2, 135-152. [Indonesian]

Liadi, P. A. (2011). Reconstruction of Financial Statements of Nonprofit Organizations in Jember Canaan Orphanage Based on PSAK Number 45 (Revised 2011. Student Research Article, 1-7. https://repository.unej.ac.id/handle/123456789/73793 [Indonesian]

Mamesah, M. (2013). Application of PSAK No. 45 on GMIM Efrata Sentrum Sonder Relation to the Quality of Information on Financial Statements. EMBA Journal, 1(4), 1717-1728. [Indonesian]

Marlinah, A., \& Ibrahim, A. (2018). Application of Nonprofit Financial Statements Based on PSAK No. 45 (Study of AlMarkaz Al-Islami Mosque, General M. Jusuf). Scientific Journal Akmen, 15(45), 170-188. [Indonesian]

Muchamad, A. S. (2011). Dissolution of Political Parties Arrangement and practice of Dissolution of Political Parties in the struggle of the Republic. Jakarta, Indonesia: Rajawali pers. [Indonesian] 
Nikmatuniayah, \& Marliyati. (2015). Accountability of Amil Zakat Financial Statements in Semarang City. Pulpit, 31(2), 485-494. [Indonesian]

Nurlaela, S., \& Mutmainah. (2014). Implementation of PSAK No. 45 in Financial Reporting for Non-profit Entities with Public Service Agency Status. Paradigm Journal, 12(45), 76-92. [Indonesian]

Pongoh, M. (2011). Analysis of Financial Statements to Assess the Financial Performance of PT Bumi Resources TBK. EMBA Journal, 1(3), 669-679. [Indonesian]

Pontoh, C. R. S. (2013). Application of Nonprofit Financial Statements Based on PSAK NO 45 at BZL Church. EMBA Journal, 1(45), 129-139. [Indonesian]

Rahman, H. I. A. (2007). Indonesian Political System. Jakarta, Indonesia: Graha Ilmu. [Indonesian]

Rahman, M. M., \& Saima, F. N. (2018). Efficiency of board composition on firm performance: Empirical evidence from listed manufacturing firms of Bangladesh. Journal of Asian Finance, Economics and Business, 5(2), 53-61. https://doi. org/10.13106/jafeb.2018.vol5.no2.53

Repi, W., Mogi-nangoi, G. B., \& Wokas, H. (2015). Analysis of the Application of PSAK NO. 45 (Revised 2011) Concerning Financial Reporting of Non-Profit Entities at STIKES Muhammadiyah Manado. Periodical Journal of Scientific Efficiency, 15(03), 168-181. [Indonesian]

Ridho, A. H. (2013). Islamic Political Parties, Theory and Practice in Indonesia. Jakarta, Indonesia: Graha Ilmu. [Indonesian]
Rohman, L. (2014). Unesa Accounting Students' Perceptions About the Effects of Transparency and Financial Accountability of Political Parties on Party Performance and Efforts to Eradicate White Collar Crime. AKUNESA Accounting Journal, 2(2), 1-23. [Indonesian]

Siswanti, T. (2017). The Effect of Reliability and Relevance of Financial Information on the Quality of Financial Statements in Air Transportation Service Companies in the Halim Perdanakusuma Airport Environment. Journal of Business \& Accounting Elements, 2(1), 49-59. [Indonesian]

Sujarweni, V. W. (2016). Introduction of accounting. Yogyakarta, Indonesia: Pustaka Baru Press. [Indonesian]

Sujarweni, V. W. (2015). Public sector accounting. Yogyakarta, Indonesia: Pustaka Baru Press. [Indonesian]

Surbakti, R., \& Supriyanto, D. (2011). Political Party Financial Control. Yogyakarta, Indonesia: Pustaka Baru Press. [Indonesian]

Tinungki, A. N. M., \& Pusung, R. J. (2014). Application of Nonprofit Financial Statements Based on PSAK No.45 at Tresna Werdha Hana Social Institution. EMBA Journal, 2(45), 809-820. [Indonesian]

Wonok, F. J. (2016). Application of PSAK No. 45 About Financial Reporting of Nonprofit Entities in the GMIM Congregation Imanuel Leilem. EMBA Journal, 4(45), 202-213. [Indonesian]

Yuliarti, N. C. (2014). Study of the Application of PSAK 45 of the Yabappenatim Orphanage Foundation, Jember. Accounting Journal, 12, 58-73. [Indonesian] 